\title{
A digitáliskompetencia-fejlesztés új eszköze: a DigKomp Rendszer
}

\author{
Sörény Edina \\ Digitális Jólét Nonprofit Kft. (Budapest) \\ soreny.edina@djnkft.hu
}

\begin{abstract}
Digital competence is a complex system of knowledge, practical skills, and behavioral elements that enables confident, critical, and creative use of digital technology-based tools and applications to make work, learning, leisure, and civic engagement more effective. Based on the 2019 data of the DESI index, the Government decided to develop a model for a digital competence development system. The Hungarian Digital Competence Framework (DigKomp System) develops and organizes tools into the system: DigKomp Learning Support Platform, DigKomp Training Register, DigKomp Certification Points, reference materials, which can serve the digital competence development of citizens more effectively than before. Keywords: digital competence, digital competence framework, competence profile, DigKomp System
\end{abstract}

\section{Bevezető}

A 2006-ban megjelent kulcskompetenciákra vonatkozó Európai Ajánlás keretében az Európai Unió a digitális kompetenciát elismerte, mint az egész életen át tartó tanuláshoz szükséges nyolc kulcskompetencia egyikét ${ }^{1}$. A digitális kompetencia ismeretek, gyakorlati képességek és viselkedési elemek komplex rendszere, amely lehetővé teszi a digitális technológián alapuló eszközök és alkalmazások magabiztos, kritikus és kreatív használatát a munkavégzés, a tanulás, a szabadidő szervezése, illetve az állampolgári aktivitás hatékonyabbá tétele céljából. A megfelelő szintű digitális jártasság ma már elengedhetetlen a világban való eligazodáshoz és az aktív léthez, továbbá a versenyképes digitális gazdaság múködéséhez is.

\section{A változás gyorsuló üteme}

Nemzetközi jövőkutatások azt vizionálják, hogy a 2030-ra olyan munkakörök jönnek létre, amelyek $85 \%$-a ma még nem létezik, ${ }^{2}$ és a ma általános iskolába járó gyermekeknek a 65\%-a teljesen új, még nem létező munkakörben fog dolgozni ${ }^{3}$. A digitális kompetencia kulcsfontosságúvá vált a foglalkoztathatóság szempontjából.

1 Ferrari, Anusca, DIGCOMP: A digitális kompetencia értelmezésének és fejlesztésének európai keretrendszere, hozzáférés: 2021.05.28.,

https://www.deaweb.hu/images/bongeszde/digcomp_teljes_hun_151231.pdf

2 The next era of human|machine partnerships:emerging technologies' impact on society \& work in 2030, hozzáférés: 2021.05.27., https://www.delltechnologies.com/content/dam/delltechnologies/ assets/perspectives/2030/pdf/SR1940_IFTFforDellTechnologies_Human-Machine_070517. readerhigh-res.pdf

3 Centeno Mediavilla, Isabel Clara;Vvuorikari, Riina; Punie, Yves et al., Developing digital competence for employability: Engaging and supporting stakeholders with the use of DigComp, hozzáférés:2021.05.29., https://publications.jrc.ec.europa.eu/repository/handle/JRC118711 
Nemcsak a szerepét tekintve transzverzális készség a foglalkoztathatóság fejlesztése érdekében, hanem azért is, mert az Európai Unió munkahelyeinek körülbelül 85\%-ában legalább alapvető digitális készségszintre van szükség ${ }^{4}$. Az előrejelzések alapján gyakoribb lesz az életciklusok során a munkahelyváltoztatás, ez akár a 15-20 munkahelyet is jelenthet. Emellett a munkakörök „tartalmának” gyors változása miatt akár már 2022re a jelenlegi munkaerő 54\%-ának átképzésre lesz szüksége. Az Európai Bizottság Közös Kutatóközpontja (Joint Research Centre - JRC) által 2019 nyarán rendezett bilbaoi workshopon elhangzott, hogy a munkavégzés formája is jelentősen át fog alakulni. Míg a 2018. évi elemzések alapján a gépi/algoritmizált és a humán munkaerő munkavégzésének aránya 29\%-71\%, addig a 2022. évi előrejelzések alapján a gépi/ algoritmizált munkavégzés 42\%-ra nő, míg ezzel párhuzamosan a humán munkaerő alkalmazása 58\%-ra csökken. (Developing digital competence for employability: Engaging and supporting stakeholders with the use of DigComp ${ }^{5}$, JRC, 2019.).

\section{Digitális környezeti kihívások}

Az Európai Uniós kutatások alapján a polgárok 45\%-ának nincs, vagy nagyon alacsony szintű a digitális tudása. A munkaerő 37\%-ának pedig nincs, vagy csak nagyon alacsony szintű a digitális kompetenciája. A vállalkozások 40\%-a IT-szakemberhiánnyal küzd. Mára a munkakörök 90\%-ánál elvárás bizonyos szintű digitális készség megléte, ami területenként eltérő. Zajlik a munkakörök átalakulása, új munkakörök létrehozása (pl.: adatgazda, azaz data steward).

A technológiai környezet gyors változása miatt az állampolgároknak hatékony, a digitális készségek fejlesztéséhez segítséget adó eszközök kifejlesztése vált szükségessé. ${ }^{6}$ Emellett az EU-ban a tagállamok digitális környezeti kihívásokra való felkészülése, felkészítése az elmúlt évek egyik kiemelt és priorizált területe. Az európai digitális menetrendhez kapcsolódóan, a digitális versenyképesség alakulásának monitorozása érdekében 2015-ben bevezetésre került a DESI index ${ }^{7}$ (Digital Economy and Society Index - Digitális Gazdaság és Társadalom Index), ami 5 területen évente méri a tagállamok digitális fejlettségét.

4 Insights into skills shortages and skill mismatch, Cedefop, 2018.-7. p.http://www.cedefop.europa.eu/en/publications-and-resources/publications/3075

5 Centeno Mediavilla, Isabel Clara; Vvuorikari, Riina; Punie, Yves et al., Developing digital competence for employability: Engaging and supporting stakeholders with the use of DigComp, hozzáférés:2021.05.29., https://publications.jrc.ec.europa.eu/repository/hndle/JRC118711

6 Hodson Deirdre, European Distance Learning Week: Tackling the digital skills gap in the EU - policies and programmes, hozzáférés: 2021.05.29., https://pt.slideshare.net/eden_online/europeandistance-learning-week-tackling-the-digital-skills-gap-in-the-eu-policies-and-programmes/4

7 The Digital Economy and Society Index (DESI), 2020., hozzáférés: 2021.05.29., https://digital-strategy.ec.europa.eu/en/policies/desi 


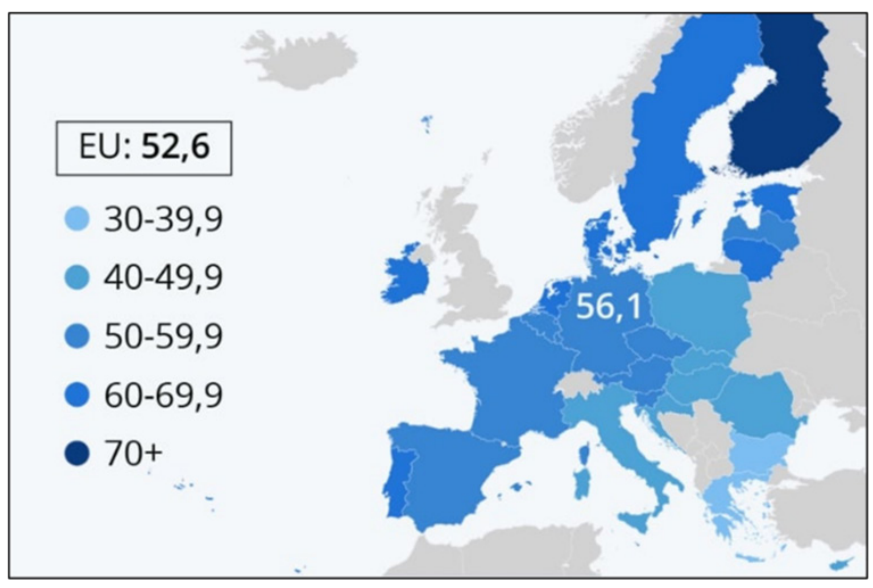

1. ábra Az EU tagállamok DESI indexe (2020)

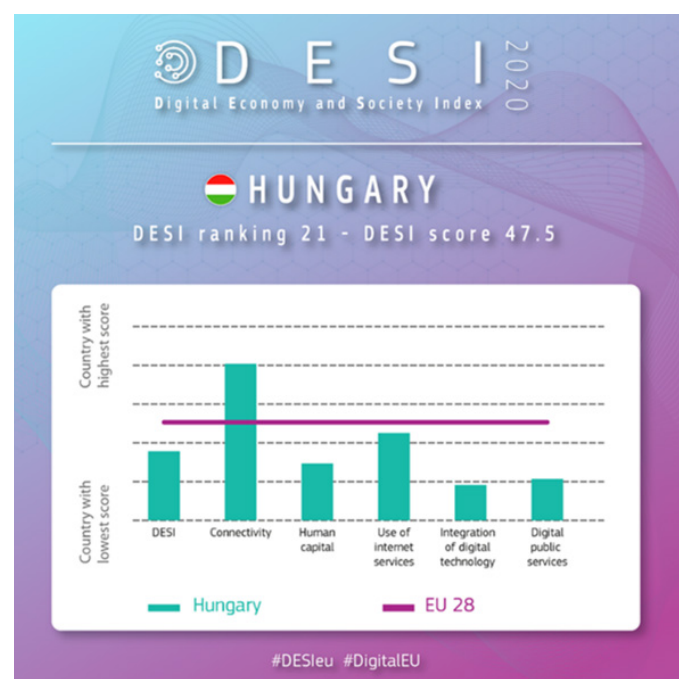

2. ábra Magyarország DESI-mérőszáma és digitális felkészültsége (2020)

\section{Miért van szükség a DigKomp Rendszerre?}

A DESI 4., Humántőke-területe méri a polgárok digitális kompetenciájának fejlődését. Ma már aligha kérdőjelezhető meg, hogy az állampolgárok digitális kompetenciájának fejlesztése elsőrendűen fontos cél, a fejlesztés sürgősségét a DESI index Magyarországra vonatkozó 2020. évi adatai is jelzik, és számos más elemzés is alátámasztja. A koronavírus-járvány következtében kialakult helyzet is rávilágított, hogy az állampolgároknak milyen sok területen van szükségük a digitális technológia használatában való magasabb szintű jártasságra. Bár a kényszer hatására sokféle hasznos és előremutató megoldás született, eközben a nyilvánvaló lemaradás is megmutatkozott.

\section{Digitális Gazdasági és Társadalmi Index - DESI 2020 Humán tőke érték (0-100), 2019}

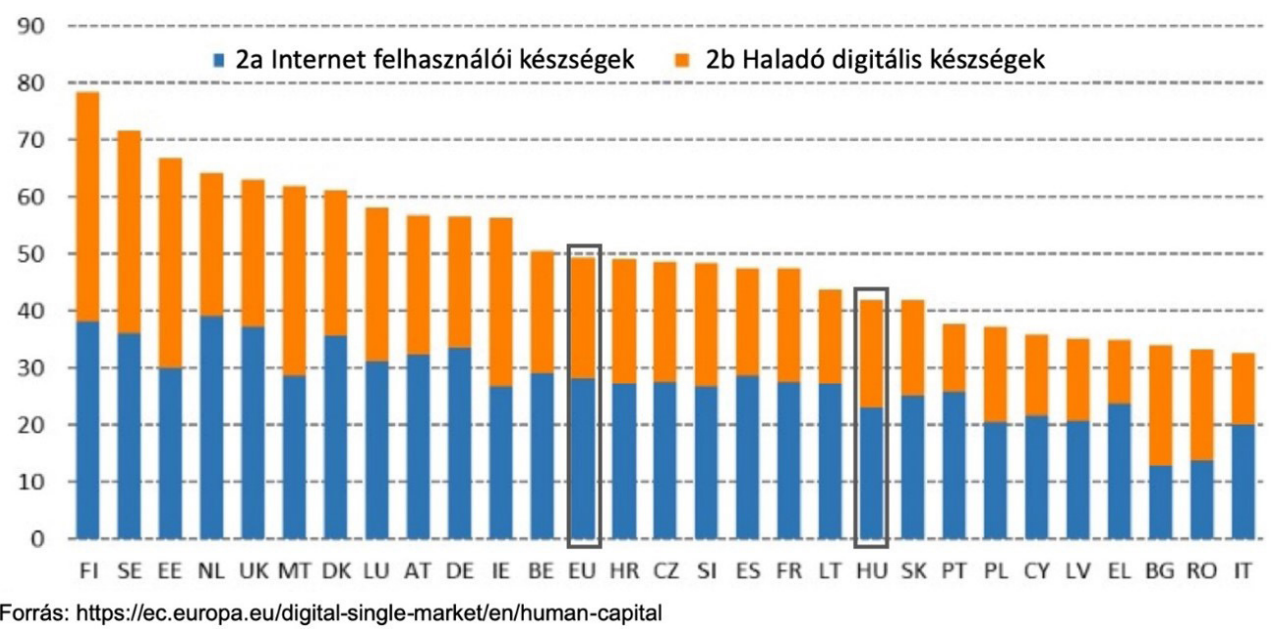

3. ábra: Humántőke-érték (0-100), Internetfelhasználói készségek 


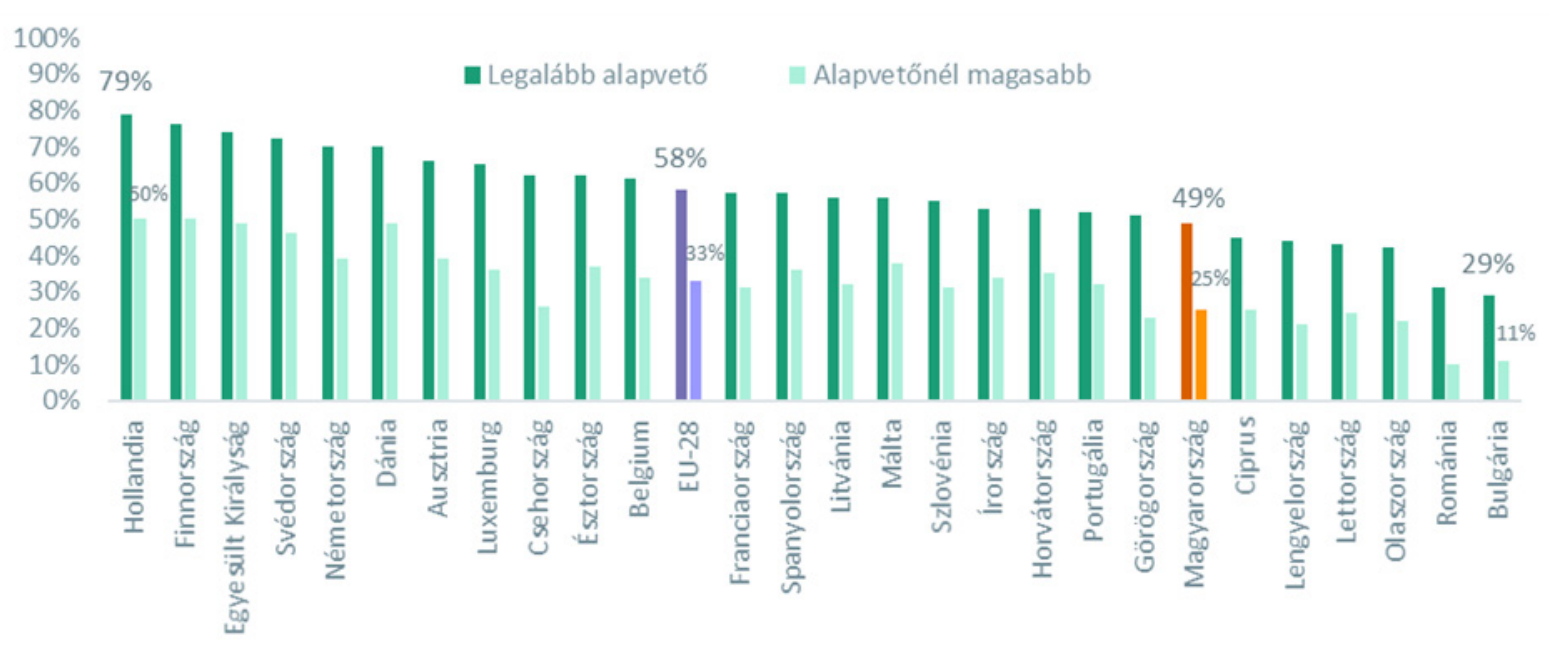

4. ábra DESI index - Digitáliskészség-szintek, EU 2020

Az állampolgárok digitális kompetenciájának fejlesztése és a versenyképes digitális gazdaság működéséhez, a megfelelő tudással rendelkező munkaerő biztosításához, az online közszolgáltatások igénybevételének növelésére és így az életminőség javításához szükséges digitális készségek magasabb szintre emelése deklaráltan kiemelt kormányzati feladattá vált, aminek eredményeként megszületett a 1341/2019 (VI.11) Korm.határozat. ${ }^{8}$ A dokumentum rendelkezett a Digitális Kompetencia Keretrendszer fejlesztéséről és bevezetésének lépéseiről, amelyben kijelölésre került a fejlesztéshez keretet biztosító GINOP 6.1.2-15-2015-00021 "Digitális szakadék csökkentése" címú projekt. A Digitális Jólét Nonprofit Kft. előkészítette egy új digitáliskompetenciafejlesztő eszközrendszer, a Digitális Kompetencia Keretrendszer (a továbbiakban: DigKomp Rendszer) fejlesztésére vonatkozó hosszú távú koncepció javaslatát, a múködési modelljét, illetve a digitális kompetencia értékelési és igazolási rendszerének lehetőségeit, továbbá a digitális készségeket fejlesztő képzések regiszterét és az ösztönzőrendszer kialakítására vonatkozó javaslatokat.

\section{A DigKomp Rendszer fő célja, elemei és működési modellje}

A tervezett DigKomp Rendszer elsődleges célja, hogy az állampolgárok digitális kompetenciájának fejlesztését rendszerszerűvé és mérhetővé tegye, mely tanúsítvánnyal igazolható. Ennek része a fejlesztési területek és célok világos, a nemzetközi referenciákkal is összhangban álló szabványos megfogalmazása, naprakészen tartása, az egyéni tanulást támogató megoldások kidolgozása, az értékelés és tanúsítás mechanizmusának kiépítése, a digitális kompetencia fejlesztésére történő ösztönzés.

8 1341/2019. (VI. 11.) Korm. határozat a Digitális Kompetencia Keretrendszer fejlesztéséről és bevezetésének lépéseiről, hozzáférés: 2021.05.29., https://net.jogtar.hu/ jogszabaly?docid=A19H1341.KOR\&timeshift=fffffff4\&txtreferer=00000001.TXT

9 GINOP-6.1.2-15 - Digitális szakadék csökkentése, hozzáférés: 2021.05.29., https://www.palyazat.gov.hu/doc/4456 
A DigKomp Rendszer olyan eszközöket fejleszt és szervez rendszerbe, amelyek az eddiginél hatékonyabban szolgálhatják az állampolgárok (például: diákok, munkavállalók, álláskeresők, fogyatékossággal élők, stb.) digitális kompetenciájának fejlesztését.

A DigKomp Rendszer tervezett fö elemei:

- a DigKomp Központ, ami a "Gépház” szerepét tölti be;

- a DigKomp Tanulástámogató Platform, ami segítséget nyújt a digitális kompetencia egyéni fejlesztéséhez, de akár csoportos tanulás keretében is használható a jövőben kifejlesztésre kerülő feladattára, illetve az azokhoz kapcsolódó tutorialtár révén;

- a DigKomp Képzési Regiszter, ami összegyűjti és strukturált módon teszi elérhetővé az információkat a digitális kompetencia fejlesztésére irányuló képzésekről és egyéb digitáliskompetencia-fejlesztő programokról;

- a DigKomp Tanúsítópontok, ahol a kompetenciaprofilokhoz kapcsolódó DigKomptanúsítvány megszerzése történik.

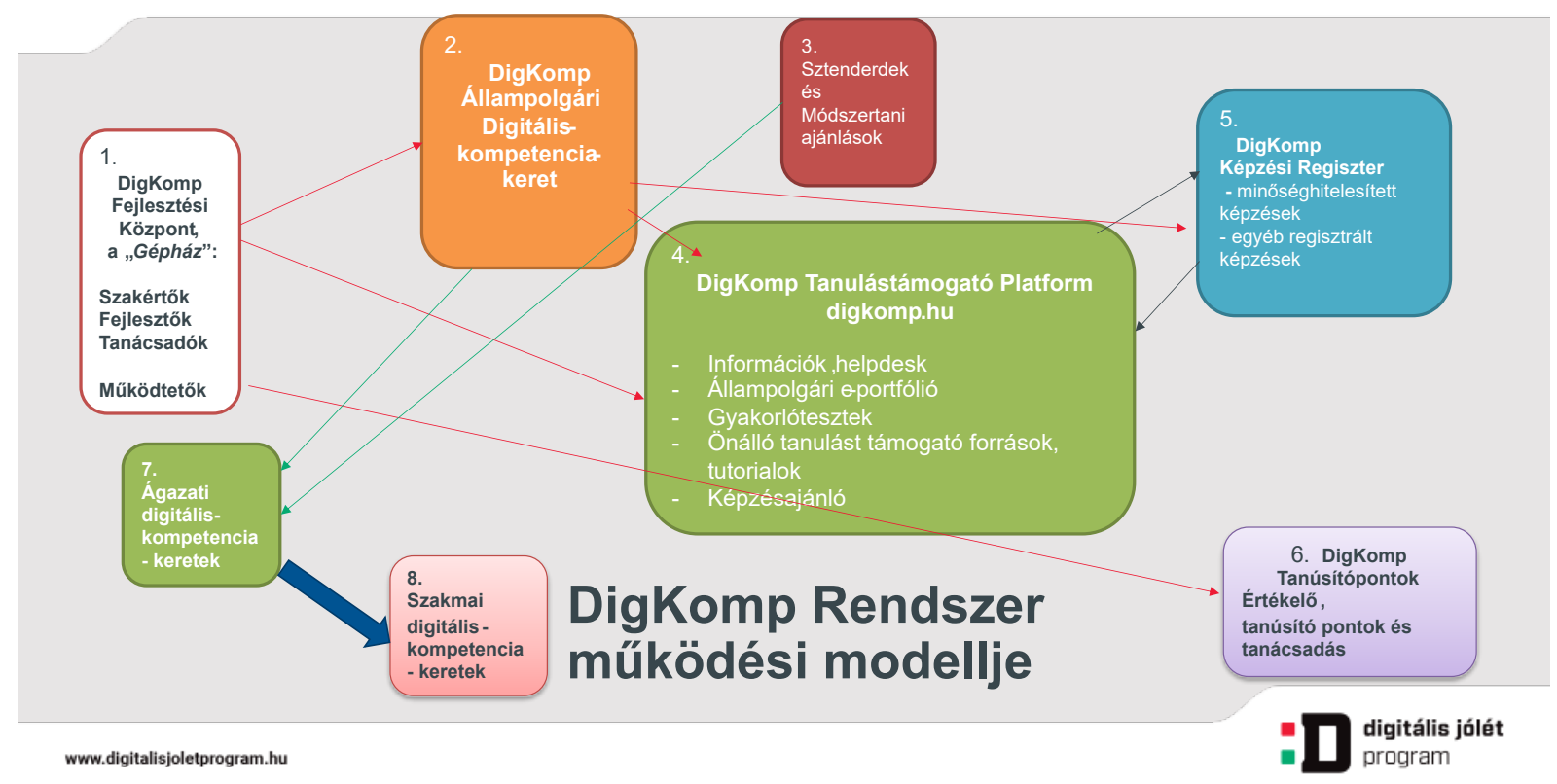

5. ábra A DigKomp Rendszer modellje

\section{DigKomp Állampolgári Digitáliskompetencia-keret - Adaptáció és Innováció}

A fejlesztés alattálló DigKomp Rendszer részét képező állampolgári digitáliskompetenciakeret olyan referenciaanyag, amely strukturált formában írja le a ma korszerūnek tartott állampolgári digitális kompetencia összetevőit. A hazai fejlesztés keretében az állampolgári keret az Európai Bizottság által 2017-ben kidolgozott és jelenleg érvényes referenciának tekintett DigComp $2.1^{10}$ állampolgári digitáliskompetencia-keret alapján került kialakításra olyan módon, hogy a hazai sajátosságok megjelenítése mellett lehetővé teszi a nemzetközi összehasonlítást is.

10 DigComp 2.1: Állampolgári digitáliskompetencia-keret, /magyarul/, 2019. hozzáférés: 2021.05.29., https://dpmk.hu/2019/07/25/a-digitalis-kompetencia-unios-referenciakerete-magyarul/ 


\begin{tabular}{|c|c|c|c|}
\hline \multicolumn{4}{|c|}{$\begin{array}{c}\text { Az Európai Uniós állampolgári digitáliskomptencia-keret fejlődése és a hazai DigKomp Állampolgári } \\
\text { Digitáliskompetencia-keret }\end{array}$} \\
\hline $\begin{array}{l}\text { DigComp } 1.0 \\
\text { EU kompetenciakeret }\end{array}$ & $\begin{array}{l}\text { DigComp } 2.0 \\
\text { EU kompetenciakeret }\end{array}$ & $\begin{array}{l}\text { DigComp } 2.1 \\
\text { EU kompetenciakeret }\end{array}$ & $\begin{array}{c}\text { DigKomp } \\
\text { Állampolgári } \\
\text { Digitáliskompetencia-keret } \\
\text { hazai kompetenciakeret }\end{array}$ \\
\hline 5 kompetenciaterület & 5 kompetenciaterület & $\begin{array}{r}2017 \\
5 \text { kompetenciaterület }\end{array}$ & 5 kompetenciaterület \\
\hline $\begin{array}{l}\text { 1. Információ /3 kompetenciaelem/ } \\
\text { 2. Kommunikáció } / 6 / \\
\text { 3. Tartalomkészítés } / 4 / \\
\text { 4. Biztonság /4/ } \\
\text { 5. Problémamegoldás /4/ } \\
21 \text { kompetenciaelem }\end{array}$ & $\begin{array}{l}\text { 1. Információ- és adatmüveltség } \\
\text { 2. Kommunikáció és közös munka } \\
\text { 3. Digitális tartalomfejlesztés } \\
\text { 4. Biztonság } \\
\text { 5. Problémamegoldás } \\
21 \text { kompetenciaelem }\end{array}$ & $\begin{array}{l}\text { 1. Információ- és } \\
\text { adatmenedzsment } \\
\text { 2. Kommunikáció és } \\
\text { együttmüködés } \\
\text { 3. Digitális tartalmak } \\
\text { 4. Biztonság } \\
\text { 5. Problémamegoldás } \\
21 \text { kompetenciaelem }\end{array}$ & $\begin{array}{l}\text { 1. Információk és adatok } \\
\text { kezelése, használata /3/ } \\
\text { 2. Kommunikáció és } \\
\text { együttmúködés } / 6 / \\
\text { 3. Digitális tartalmak } \\
\text { létrehozása /4/ } \\
\text { 4. Biztonság /4/ } \\
\text { 5. Különféle problémák } \\
\text { kezelése } / 4 \text { / } \\
21 \text { kompetenciaelem }\end{array}$ \\
\hline 3 jártassági szint & 8 jártassági szint & 8 jártassági szint & 8 jártassági szint \\
\hline $\begin{array}{l}\text { Alapszint /A/ } \\
\text { Középszint /B/ } \\
\text { Felsőszint /C/ }\end{array}$ & $\begin{array}{l}\text { Alapszint /A/ } \\
\text { Középhaladó/B/ } \\
\text { Haladó/C/ } \\
\text { Magasan specializált v2.0 }\end{array}$ & $\begin{array}{l}\text { Alapszint /1-2/ } \\
\text { Középszint/3-4/ } \\
\text { Haladó szint /5-6/ } \\
\text { Mesterszint /7-8/ }\end{array}$ & $\begin{array}{l}\text { Alapszint /1-2/ } \\
\text { Középszint/3-4/ } \\
\text { Haladó szint /5-6/ } \\
\text { Mesterszint /7-8/ }\end{array}$ \\
\hline $\begin{array}{l}\text { https://ec.europa.eu//irc/en/publication/di } \\
\text { gcomp-framework-developing-and- } \\
\text { understanding-digital-competence- } \\
\text { europe } \\
\text { https://www.deaweb.hu/images/bongesz } \\
\text { de/digcomp teljes hun 151231.pdf }\end{array}$ & $\begin{array}{l}\text { https://ec .europa.eu/irc/en/publication } \\
\text { leur-scientific-and-technical- } \\
\text { research-reports/digcomp-20-digital- } \\
\text { competence-framework-citizens- } \\
\text { update-phase-1-conceptual- } \\
\text { reference-model }\end{array}$ & $\begin{array}{l}\text { https://ec.europa.eu/irc/en/publicati } \\
\text { on/eur-scientific-and-technical- } \\
\text { research-reports/digcomp-21- } \\
\text { digital-competence-framework- } \\
\text { citizens-eight-proficiency-levels- } \\
\text { and-examples-use }\end{array}$ & munkaanyag \\
\hline
\end{tabular}

\section{6. ábra A DigComp-tól a DigKomp-ig}

A hazai állampolgári keret (DigKomp ÁDKK) döntő mértékben az uniós referencia, a DigComp 2.1 keret szerkezetétés szintezésialapelveit követi, ami 5 kompetenciaterületet, 21 kompetenciaelemet és ahhoz kapcsolódó 8 jártassági szintet tartalmaz.

A hazai fejlesztés hozzáadott elemei:

- Törekvés az online szolgáltatásokkal kapcsolatos kompetenciaelemek megjelenítésére a gyakorlati példákon keresztül.

- A kompetenciaterületek megnevezésének és a kompetenciaelemek deskriptorainak pontosítása.

- Hazai környezetben értelmezhető példák készítése - a privát élettérben és a munka világához kapcsolódóan. (Teljes példarendszer létrehozása: minimum 500 példa).

- Szintdefiníció készítése (168) - minden kompetenciaelemhez, minden jártassági szinten készült szintdefiníció a tananyagfejlesztők és a képzésszervezők támogatása érdekében.

- Új dimenziók létrehozása: belső területközi kapcsolódások jelzése.

- Profilban való gondolkodás - cél az aktuális digitális tudás profilalapú értékelése, valamint előre definiált digitáliskomptencia-profiljavaslatok megalkotása. Az alapszintű digitális készségszintre előre definiált profil a DigKomp Állampolgári Bázis és a magasabb, haladó szintű digitális készségszintre az Állampolgári Plusz létrehozása.

- A DigKomp ÁDKK módszertani előkép az ágazati, szakmai keretekhez. A tervezett DigKomp Rendszer nemzetközileg is egyedi vonása, hogy az állampolgárok 
digitális kompetenciájának fejlesztését szolgáló eszközök mellett a gazdaság számára szükséges ágazati és szakmai szintű digitáliskompetencia-fejlesztéshez is eszközöket kíván nyújtani. Erre szolgál az ágazati digitáliskompetenciakeretek kidolgozása, az azok alapján kidolgozandó szakmai digitáliskompetenciaelvárások megfogalmazása, illetve az azt segítő módszertani útmutató.

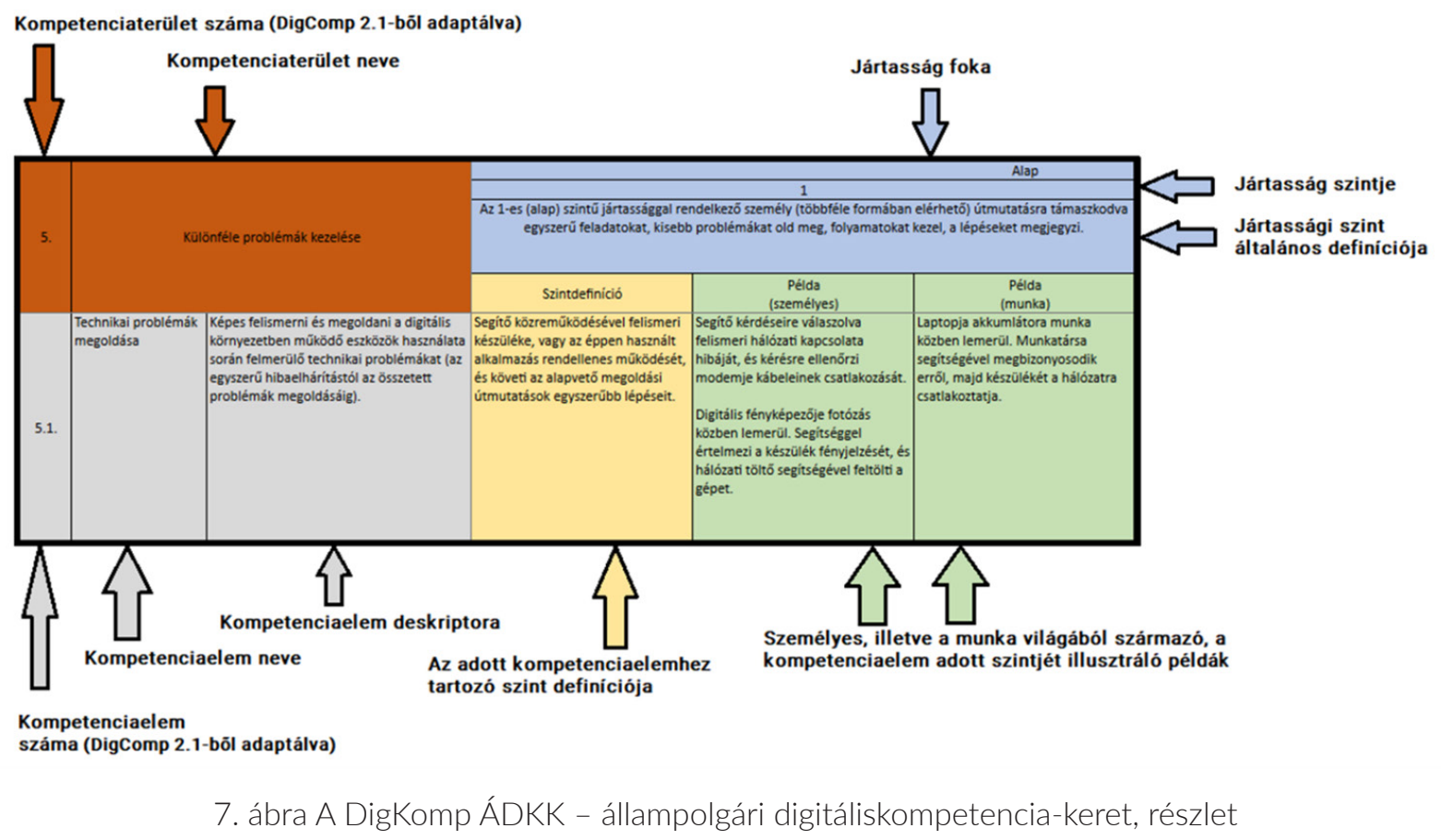

\section{7. Összefoglaló}

Kijelenthetjük, hogy a népesség digitális kultúrájának és gyakorlati készségeinek fejlesztése hosszú távú feladat. A digitális technológia gyors fejlődése és annak elterjedése ma már potenciálisan az egész lakosságot érinti. A DigKomp Rendszer egyidejüleg képes a digitálisan legkevésbé jártas népesség kompetenciafejlesztésére, de a magas felkészültségi szinttel rendelkezőket is további tanulásra és fejlődésre ösztönzi. A hazai digitális tudás és jártasság fejlődése Magyarország DESI értékeinek fokozatos növekedésére, valamint a munkavállalók munkaerőpiaci elhelyezkedésének esélyeire is hatással van, továbbá támogatja a Nemzeti Digitalizációs Stratégia által 2030-ra megfogalmazott célértékeket is. 


\section{Bibliográfia}

Carretero Gomez Stephanie; Vuorikari Riina; Punie Yves. DigComp 2.1: The Digital Competence Framework for Citizens with eight proficiency levels and examples of use. 2017. https://ec.europa.eu/jrc/en/publication/eur-scientific-and-technicalresearch-reports/digcomp-21-digital-competence-framework-citizens-eightproficiency-levels-and-examples-use

Centeno Mediavilla, I., Vuorikari, R., Punie, Y., Okeeffe, W., Kluzer, S., Vitorica, A., Lejarzegi, R., MartÃnez De Soria, I. and BartolomÃ $\subset$, J., Developing digital competence for employability: Engaging and supporting stakeholders with the use of DigComp, Publications Office of the European Union, Luxembourg, 2019.

https://publications.jrc.ec.europa.eu/repository/handle/JRC118711

Ferrari, Anusca. DIGCOMP: A Framework for Developing and Understanding Digital Competence in Europe., 2013. https://ec.europa.eu/jrc/en/publication/digcompframework-developing-and-understanding-digital-competence-europe

Ferrari, Anusca. DIGCOMP: A digitális kompetencia értelmezésének és fejlesztésének európai keretrendszere, 2013. https://www.deaweb.hu/images/bongeszde/ digcomp_teljes_hun_151231.pdf

The Future of Jobs Employment, Skills and Workforce Strategy for the Fourth Industrial Revolution, World Economic Forum, 2016. http://reports.weforum.org/future-ofjobs-2016/chapter-1-the-future-of-jobs-and-skills/\#view/fn-1

Hodson, Deirdre. European Distance Learning Week: Tackling the digital skills gap in the EU - policies and programmes, 2016. https://pt.slideshare.net/eden_online/ european-distance-learning-week-tackling-the-digital-skills-gap-in-the-eu-policiesand-programmes/4

Insights into skills shortages and skill mismatch: Learning from Cedefop's European skills and jobs survey, Cedefop. 2018. http://www.cedefop.europa.eu/en/publicationsand-resources/publications/3075

The next era of human|machine partnerships: emerging technologies' impact on society \& work in 2030. Institute for the Future for Dell Technologies, 2017. https://www. delltechnologies.com/content/dam/delltechnologies/assets/perspectives/2030/ pdf/SR1940_IFTFforDellTechnologies_Human-Machine_070517_readerhigh-res. $\underline{\text { pdf }}$

Vuorikari Riina; PUNIE Yves; Carretero Gomez Stephanie; Van den Brande Godelieve. DigComp 2.0: The Digital Competence Framework for Citizens. Update Phase 1: the Conceptual Reference Model, 2016. https://ec.europa.eu/jrc/en/publication/ eur-scientific-and-technical-research-reports/digcomp-20-digital-competenceframework-citizens-update-phase-1-conceptual-reference-model 